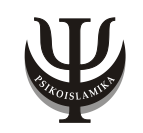

\title{
Peran Stresor Harian, Optimisme dan Regulasi Diri terhadap Kualitas Hidup Individu dengan Diabetes Melitus Tipe 2
}

\begin{abstract}
The aim of this research is to analyze the role of daily stress, optimsm and self regulation toward the quality of life of type 2 individual with diabetic mellitus. The hypothesis of this research are: 1). There is a negative relationship between daily stress and quality of life; 2). Optimsm as moderate relation between daily stress and quality of life; 3). Autonom self regulation as moderate relation between daily stress and quality of life; 4). Controlled self regulation as mediator relation daily stress and quality of life. Research Methodology: The research is conducted among individuals who were diagnosed with type 2 diabetic mellitus in Sardjito Hospital Yogyakarta. There are 64 subjects who completed the research tools (daily stress, optimism, self regulation and quality of life scale) started from January $4^{\text {th }}-$ February $12^{\text {nd }}$ 2010. The research shows that there is a negative relation between daily stress and quality of life $(\mathrm{r}=0,265 ; \mathrm{F}=22,304 ; \mathrm{p}=0,000 ; \mathrm{p}<0,01$; significant $)$. The result of moderate regression analysis shows optimsm is not moderate variable, but autonom self regulation is moderate variable $(\beta=0,004 ; p<0,001$; significant).

The result of path analysis shows that controlled self regulation is mediator relation of daily stress and quality of life ( $p=0,045 ; p<0,05$; significant). There is a negative significant relation between daily stress and quality of life. Optimism is not significant as moderate variable relation between daily stress and quality of life. Autonom regulation is significant as moderate relation between daily stress and quality of life. Controlled self regulation is significant as mediator relation of daily stress and quality of life.
\end{abstract}

KEYWORDS: quality of life, daily stress, optimism, self regulation and type 2 diabetic patient.

Melina Dian Kusumadewi

Pascasarjana Universitas Gadjah Mada Yogyakarta

kusumadewi12@gmail.com

PSIKOISLAMIKA, Jurnal Psikologi Islàm (JPI) Copyright (c 2011 Lembaga

Penelitian Pengembangan dan Keislaman (LP3K pbb3:No.1 2011 43-62

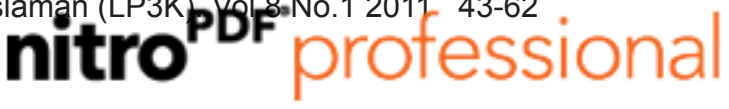




\section{Muqadimah}

Diabetes melitus tipe 2 telah menjadi masalah kesehatan masyarakat di seluruh dunia khususnya di negara berkembang. Diabetes melitus merupakan penyakit yang paling kompleks dan menuntut banyak perhatian maupun usaha dalam pengelolaannya dibandingkan dengan penyakit kronis lainnya, karena penyakit diabetes tidak dapat diobati namun hanya dapat dikelola.

Tujuan pengelolaan diabetes adalah menghilangkan keluhan atau gejala, mempertahankan rasa nyaman dan sehat, mencegah timbulnya komplikasi, menurunkan angka kesakitan dan kematian. Tujuan ini dapat tercapai apabila kadar gula darah terkontrol. Oleh karena itu, individu dengan diabetes harus mengatur pola makan dengan makanan yang sehat, rendah lemak dan cukup hidrat arang, menjalani pemeriksaan gula darah, berolah raga secara teratur, menjaga keseimbangan berat badan serta menggunakan obat sesuai anjuran dokter (Perkeni, 2008). Menurut Asdie (2000) mempertahankan kualitas hidup merupakan salah satu tujuan utama pengobatan penyakit diabetes melitus.

Kontrol gula darah merupakan salah satu indikator kualitas hidup individu dengan diabetes karena kontrol gula darah yang baik menjadi salah satu parameter kesuksesan penyesuaian pada pola hidup (Prokop, Bradley, Burish, Anderson \& Fox 1991). Gula darah yang tidak terkontrol, baik hyperglycemia (kadar gula sangat tinggi) atau hypoglycemia (kadar gula darah sangat rendah), akan menyertai kemunculan simtom-simtom diabetes.

Pada saat penderita diabetes mengalami tingkat gula darah yang tinggi (hyperglycemia), penderita akan merasa sangat haus, sering buang air kecil, sakit kepala, mudah lelah dan mudah merasa tersinggung. Sementara itu jika mengalami kadar gula darah yang sangat rendah (hypoglycemia), penderita akan mudah berkeringat, lapar, penglihatan terganggu, merasa lemas, mengalami gangguan koordinasi motorik, kebingungan mental dan merasa cemas (Pitts \& Phillips, 1991).

Munculnya gejala yang diakibatkan oleh kadar gula yang tidak terkontrol ini dapatentenggthngu aktivitas individu sehari-hari 
dan menurunkan fungsi individu secara keseluruhan baik fungsi fisik, psikologis dan sosial. Individu dengan diabetes akan merasa energinya berkurang sehingga mudah lelah dalam melakukan aktivitas sehari-hari, dan menyebabkan aktivitas fisik serta peran dan tanggungjawabnya menjadi berkurang. Selain fungsi fisik yang terganggu, perasaan cemas dan mudah tersinggung juga menimbulkan keterbatasan dalam aktivitas sosial. Hal-hal tersebut menyebabkan individu merasa kurang sejahtera dan mengurangi kualitas hidup.

\section{Kerangka Kerja Teoritik}

Kualitas hidup penderita diabetes melitus dipengaruhi oleh berbagai faktor baik secara medis, maupun psikologis. Berbagai faktor tersebut diantaranya adalah pemahaman terhadap diabetes, penyesuaian terhadap diabetes, depresi, regulasi diri (Watkins, Connell, Fitzgerald, Klem, Hickey \& Dayton, 2000) emosi negatif, efikasi diri, dukungan sosial, komplikasi mayor (kebutaan, dialysis, neuropati, luka kaki, amputasi, stroke dan gagal jantung), karakteristik kepribadian dan perilaku koping (Rose et al., 1998; 2002), tipe dan lamanya diabetes, tritmen diabetes, kadar gula darah, locus of control, jenis kelamin, tingkat pendidikan, usia, status perkawinan dan edukasi diabetes (Milencovic et al., 2004; Akimoto et al., 2004), emotional distres yang berhubungan dengan diabetes (Polonsky, Fisher, Earles, Dudl, Lees, Mullan \& Richard, 2005), adanya stres, peristiwa kehidupan dan stresor harian (Nakahara et al., 2006).

Karakteristik pengelolaan diabetes yang berlaku sepanjang usia individu tersebut, menuntut kemampuan individu untuk menyesuaikan diri terhadap pola hidup melalui manajemen diri. Keberhasilan manajemen diri mengharuskan individu menerapkan proses regulasi diri (Petrie et al., 2002). Regulasi diri ini harus dilakukan dengan cara monitoring terhadap simtom dan kadar gula darahnya serta mampu mendeteksi pada saat kapan mengalami hipoglikemia atau hiperglikemia.

Pada penelitian Watkins et al. (2000) menunjukkan bahwa regulasi diri berhubungan dengan meningkatnya perilaku sehat penderita diabetes, menurunkan rasa terbebani dan menghasilkan kualitas hidup yang baik. Lebih lanjut penelitian Williams et al. (2004) menemukan bahwa penentuan diri (self determination) dapat memprediksi rerata gula darah yang terksptel (nilai $\mathrm{HbA1c}$ ), 
melalui perubahan motivasi otonom dan kompetensi. Sementara itu, pada penelitian William et al. (1998) menunjukkan bahwa pasien diabetes yang menerima dukungan otonomi dari para dokter akan menjadi lebih termotivasi untuk meregulasi kadar gula darahnya, lebih mampu untuk meregulasi gula darahnya dan menunjukkan perbaikan nilai $\mathrm{HbA1c}$.

Fakta yang ada sekarang adalah faktor psikologis seperti stres dapat menyebabkan kadar gula menjadi tidak terkontrol sehingga dapat memunculkan simtom-simtom diabetes melitus, baik simtom hiperglikemia maupun simtom hipoglikemia (Pitt \& Phillips, 1991).

Vitaliano et al. (1996) menyatakan bahwa faktor psikologis seperti stresor harian, rasa marah, sikap bermusuhan, dan dukungan sosial berhubungan erat dengan tinggi rendahnya insulin dan kadar gula darah pasien diabetes. Hubungan antara tingkat stres dengan kontrol kadar gula darah merupakan hal yang sangat penting diperhatikan (Riazi et al., 2004).

Beberapa studi melaporkan bahwa faktor-faktor psikologis berhubungan erat dengan kontrol gula darah, seperti kejadian seharihari, ada tidaknya stres, dukungan sosial, dan efikasi diri (Bradly; Mooy et al. ; Aikens et al.; Glasgow et al. ; Fukunishi et al. ; Toobert \& Glasgow; Kavanagh et al. ; Talbot et al., dalam Nakahara et al., 2006).

Penelitian Vitaliano et al. (2006) menunjukkan bahwa subjek dengan tingkat stresor harian yang tinggi ternyata memiliki kadar gula darah yang lebih tinggi secara signifikan daripada subjek dengan tingkat stresor harian yang lebih rendah. Lebih lanjut Vitaliano mengatakan bahwa tekanan kehidupan dan stresor harian secara positif berhubungan dengan kadar gula darah dan rendahnya kontrol metabolisme. Stresor harian dapat mengurangi kesejahteraan psikologis dalam jangka pendek dan menghasilkan simtom fisik, sehingga stresor harian dapat menghasilkan stres dan memperburuk kesehatan fisik dan psikologis (Serido, Almeida \& Wethington, 2004).

Selain stresor harian, penelitian lain menunjukkan bahwa faktor kepribadian juga berpengaruh cukup besar terhadap kemampuan mengontrol gula darah dan kualitas hidup individu dengan diabetes melitus. Penelitian Rose et al. (2002) menunjukkan bahwa faktor kepribadian dapat memperburuk kualitas hidup, terlepas dari penderitaan yang diakibatkan penyakit fisik dapjumlah komplikasi 
yang muncul. Dari penelitian tersebut ditemukan bahwa pasien yang lebih optimis terhadap masa depan dan mempunyai efikasi diri yang tinggi, dilaporkan memiliki kualitas hidup yang lebih baik, meskipun pada pasien tersebut menderita penyakit sekunder. Individu yang optimis memiliki motivasi dan keinginan untuk mengambil bagian dalam proses terapi. Motivasi dan keinginan untuk berpartisipasi dalam terapi merupakan fondasi penting dalam melakukan manajemen diri yang baik dan menghasilkan kadar gula darah yang optimal karena kualitas hidup pada individu dengan diabetes dipengaruhi oleh pengaturan kadar gula darah (Rose et al., 2002).

Penelitian yang dilakukan oleh Wrosch dan Scheier (2003) menemukan bahwa pada individu yang optimis, lebih terfokus pada masalah dalam menghadapi stres, lebih aktif dan terencana dalam berkonfrontasi dengan peristiwa yang menekan serta menggunakan kerangka berpikir yang positif. Individu yang optimis juga lebih sedikit menyalahkan diri sendiri dan lari dari masalah serta tidak fokus pada aspek negatif permasalahan. Bahkan ketika strategi koping yang berfokus pada masalah tidak memungkinkan, orangorang yang optimis akan melakukan strategi koping berfokus emosi yang adaptif seperti penerimaan, humor dan kerangka berpikir yang positif (Wrosch \& Scheier, 2003).

Dengan demikian secara jelas dapat dilihat bahwa kemampuan untuk mengontrol kadar gula darah memiliki peranan yang sangat penting. Hal ini tidak terlepas dari faktor-faktor seperti stresor harian, optimisme dan regulasi diri. Berdasarkan penjelasan tersebut maka peneliti ingin menguji peran stressor harian, optimism dan regulasi diri terhadap kualitas hidup individu dengan diabetes melitus tipe 2. Adapun hipotesis yang diajukan dalam penelitian ini adalah:

1. Hipotesis Mayor:Ada hubungan antara stresor harian, optimisme, regulasi diri dengan kualitas hidup individu dengan diabetes melitus tipe 2 .

2. Hipotesis Minor:

a). Stresor harian berhubungan negatif dengan kualitas hidup. Semakin tinggi stresor harian maka kualitas hidup semakin rendah.

\section{Created with}


b). Tingkat optimisme yang tinggi dapat menurunkan pengaruh stresor harian terhadap kualitas hidup.

c). Regulasi diri otonom dapat menurunkan pengaruh stresor harian terhadap kualitas hidup.

d). Stresor harian yang tinggi mempengaruhi kualitas hidup melalui regulasi diri terkontrol.

\section{Metode}

Karakteristik subjek penelitian adalah pasien diabetes melitus tipe 2 yang berusia 30 sampai 59 tahun, yang didapatkan dari hasil diagnosis dokter, telah menjalani pengobatan selama minimal 1 tahun. Subjek bersedia terlibat dalam penelitian tanpa paksaan, telah mendapat penjelasan tentang tujuan, akibat dan manfaat penelitian, dan telah menandatangani informed consent. Subjek penelitian berjumlah 64 orang.

Metode pengumpulan data yang digunakan dalam penelitian ini adalah metode kuantitatif dengan menggunakan Skala Stresor Harian yang terdiri dari sub skala stresor harian umum dan sub skala stresor harian diabetes melitus, Skala Optimisme, Skala Regulasi Diri, dan Kualitas Hidup.

Analisis data yang digunakan dalam penelitian ini adalah analisis statistic dengan bantuan SPSS. Uji hipotesis penelitian dilakukan dengan metode analisis regresi untuk melihat kemampuan prediksi prediktor (yaitu: stresor harian, optimisme dan regulasi diri) terhadap kriterium (yaitu: kualitas hidup). Uji regresi dengan variabel moderating menggunakan Moderate Regression Analysis, yaitu aplikasi khusus regresi berganda linier yang persamaan regresinya mengandung unsur interaksi (perkalian variabel stresor harian dengan variabel optimisme dan perkalian variabel stresor harian dengan regulasi diri otonom), sedangkan uji regresi dengan variabel intervening/ mediator menggunakan analisis jalur (Path Analysis).

\section{Hasil}

Hipotesis Mayor:

Hipotesis mayor berbunyi "Ada hubungan antara stresor harian, optimisme dan regulasi diri dengan kualitas hidup". Hipotesis ini diuji dengan analisis regresi ganda. Hasilanalisis didapatkan $\mathrm{F}$ 
sebesar $=6,194 ; \mathrm{r}=0,544 ; \mathrm{p}=0,000 ; \mathrm{p}<0,01$ (sangat signifikan); dan $\mathrm{R}$ ${ }^{2}=0,296$.

Hasil ini menunjukkan bahwa ada hubungan yang sangat signifikan antara stresor harian, optimisme dan regulasi diri dengan kualitas hidup, pada taraf signifikansi 1\% dengan sumbangan efektif sebesar 29,6\%. Dengan demikian hipotesis yang menyatakan bahwa ada hubungan antara stresor harian, optimisme dan regulasi diri dengan kualitas hidup diterima.

Hipotesis Minor Pertama:

Stresor harian berhubungan negatif dengan kualitas hidup. Hasil analisis untuk stresor harian didapatkan $\mathrm{F}$ sebesar $=22,304 ; \mathrm{r}$ $=-0,514 ; p=0,000 ; p<0,01$ (sangat signifikan) dan $R^{2}=0,265$. Hasil ini menunjukkan bahwa ada hubungan yang signifikan antara stresor harian dengan kualitas hidup, pada taraf signifikansi 1\% dengan sumbangan efektif sebesar 26,5\%. Dengan demikian hipotesis yang menyatakan bahwa ada hubungan negatif antara stresor harian dengan kualitas hidup diterima.

Tabel 1

Hasil Analisis Regresi Ganda Stresor Harian dengan Kualitas Hidup

\begin{tabular}{ccccccc}
\hline $\mathrm{t}$ & $\mathrm{RX1Y}$ & $\mathrm{R}^{2}$ & $\mathrm{Df}$ & $\mathrm{F}$ & $\begin{array}{c}\text { Signifi- } \\
\text { kansi }\end{array}$ & $\begin{array}{c}\text { Ketera- } \\
\text { ngan }\end{array}$ \\
\hline $\begin{array}{c}\text { Stresor } \\
\text { harian }\end{array}$ & 0,514 & 0,265 & $1 / 63$ & 22,304 & 0.000 & $\begin{array}{c}\text { Sangat } \\
\text { signifi- } \\
\text { kan }\end{array}$ \\
\hline
\end{tabular}

Hipotesis Minor Kedua:

Tingkat optimisme yang tinggi dapat menurunkan pengaruh stresor harian terhadap kualitas hidup. Hasil Moderate Regression Analysis menunjukkan bahwa variabel optimisme bukan merupakan variabel moderator (beta $=-0,087 ; p=0,902: p>0,05$ : tidak signifikan). Dengan demikian hipotesis yang menyatakan bahwa tingkat optimisme yang tinggi dapat menurunkan pengaruh stresor harian terhadap kualitas hidup ditolak.

\section{Created with}


Tabel 2

Hasil Moderate Regression Analysis Stresor Harian-Optimisme dengan Kualitas Hidup

\begin{tabular}{|c|c|c|c|c|c|c|}
\hline & \multicolumn{2}{|c|}{$\begin{array}{l}\text { Unstandardized } \\
\text { Coefficients }\end{array}$} & \multirow{2}{*}{$\begin{array}{c}\begin{array}{c}\text { Standardizes } \\
\text { Coefficients }\end{array} \\
\text { Beta }\end{array}$} & \multirow{2}{*}{$t$} & \multirow{2}{*}{ Sig } & \multirow{2}{*}{ Ket } \\
\hline & B & $\begin{array}{l}\text { Std. } \\
\text { Error }\end{array}$ & & & & \\
\hline $\begin{array}{c}\text { Moder- } \\
\text { atSH- } \\
\text { Opt }\end{array}$ & $-0,001$ & 0,010 & $-0,087$ & $-0,123$ & 0,902 & $\begin{array}{l}\text { Tidak } \\
\text { signi- } \\
\text { fikan }\end{array}$ \\
\hline
\end{tabular}

Hipotesis Minor Ketiga:

Regulasi diri otonom dapat menurunkan pengaruh stresor harian terhadap kualitas hidup. Hasil Moderate Regression Analysis ditemukan nilai $\mathrm{F}$ sebesar $=12,024 ; \mathrm{p}=0,000 ; \mathrm{p}<0,01$ (sangat signifikan), $\quad r=0,613$ dan $R^{2}=0,375$. Signifikansi $\beta$ moderator regulasi diri otonom $p=0,004 ; p<0,01$ (sangat signifikan). Hasil ini menunjukkan bahwa ada hubungan antara stresor harian dan regulasi diri otonom secara bersama-sama dengan kualitas hidup. Hubungan tersebut signifikan pada taraf signifikansi $1 \%$ dengan sumbangan efektif sebesar $37,5 \%$. Regulasi diri otonom sebagai varibel moderator terbukti mempengaruhi hubungan stresor harian dengan kualitas hidup dengan taraf signifikansi 1\%. Dengan demikian hipotesis yang menyatakan bahwa regulasi diri otonom dapat menurunkan pengaruh stresor harian terhadap kualitas hidup diterima.

\section{Hipotesis Minor Keempat:}

Stresor harian yang tinggi mempengaruhi kualitas hidup melalui regulasi diri yang terkontrol. Hasil analisis regresi hubungan stresor harian terhadap regulasi diri terkontrol didapatkan nilai $\mathrm{F}=$ 8,896; $r=0,354 ; p=0,004 ; p<0,01$ (sangat signifikan), dan $R^{2}=0,125$. Hasil analisis regresi hubungan regulasi diri terkontrol terhadap kualitas hidup didapatkan nilai $F=6,427 ; \mathrm{r}=0,306 ; \mathrm{p}=0,014 ; \mathrm{p}<0,01$ (sangat signifikan), dan $\mathrm{R}^{2}=0,094$. Taraf signifikansi mediator $\mathrm{p}=$ 0,045; $\mathrm{p}<0,05$ (signifikan).

\section{Created with}


Hasil ini menunjukkan bahwa ada hubungan antara stresor harian terhadap regulasi diri terkontrol dengan taraf signifikansi 1\%, dengan sumbangan efektif $12,5 \%$ dan ada hubungan antara regulasi diri terkontrol dengan kualitas hidup dengan taraf signifikansi 5\% dengan sumbangan efektif 9,4\%. Regulasi diri terkontrol terbukti sebagai mediator pengaruh stresor harian terhadap kualitas hidup dengan taraf signifikansi 5\%. Ini menunjukkan bahwa stresor harian berpengaruh terhadap kualitas hidup melalui regulasi diri terkontrol.

Dengan demikian hipotesis yang menyatakan bahwa stresor harian yang tinggi mempengaruhi kualitas hidup melalui regulasi diri yang terkontrol diterima.

\section{Diskusi}

Secara umum, berdasarkan hasil analisis data penelitian ditemukan bahwa hipotesis mayor yang diajukan terbukti kebenarannya, dan satu dari keempat hipotesis minor tidak terbukti kebenarannya. Hasil penelitian membuktikan bahwa ada hubungan antara stresor harian, optimisme dan regulasi diri secara bersamasama dengan kualitas hidup. Hubungan tersebut signifikan pada taraf signifikansi $1 \%$ dengan sumbangan efektif sebesar 29,6\% ( F = 6,194; $r=$ $0,544 ; p=0,000 ; p<0,01)$. Ini berarti sebesar 29,6\% variasi kualitas hidup dapat dijelaskan dari variabel stresor harian, optimisme dan regulasi diri, sedangkan sisanya sebesar 70,4\% dijelaskan oleh faktor lain.

Hasil uji hipotesis minor penelitian ini menemukan adanya hubungan antara stresor harian dengan kualitas hidup. Hubungan tersebut signifikan pada taraf signifikansi $1 \%$ dengan sumbangan efektif sebesar 26,5\% ( $F=22,304 ; r=-0,514 ; p=0,000 ; p<0,01)$. Hal ini berarti bahwa sebanyak $26,5 \%$ variasi kualitas hidup secara langsung dipengaruhi oleh stressor harian. Hasil penelitian ini mendukung hasil penelitian yang dilakukan oleh Nakahara et al. (2006) bahwa stres harian baik stres yang bersumber dari kejadian sehari-hari (daily hassles) maupun stres harian terkait diabetes (diabetes related distress) mempengaruhi kualitas hidup.

Goldney et al. (2004) menyatakan bahwa pasien dengan distres yang tinggi mempunyai kualitas hidup yang buruk. Berdasarkan data subjek penelitian ini ditemukan bahwşsyjek yang memiliki 
kualitas hidup yang sangat tinggi sebanyak 50\%, subjek yang memiliki kualitas hidup tinggi sebanyak 31,25\%, kualitas hidup sedang sebanyak $14,06 \%$ dan kualitas hidup rendah sebanyak 1,56\%, sementara subjek yang memiliki tingkat stressor harian yang sangat rendah sebanyak $96,87 \%$ dan rendah sebanyak 3,12\%. Memperhatikan gambaran subjek penelitian tersebut, dapat dikatakan bahwa subjek penelitian ini memiliki kualitas hidup yang baik dengan tingkat stresor harian yang rendah.

Hasil analisis tambahan penelitian ini menemukan adanya perbedaan sumbangan antara stresor harian umum dengan stresor harian terkait diabetes terhadap kualitas hidup. Sumbangan stresor harian umum didapatkan 20,6\% ( $F=16,071 ; \mathrm{r}=-0,454 ; \mathrm{p}=0.000$; $\mathrm{p}<0,01)$, sedangkan sumbangan stresor harian terkait diabetes didapatkan sebesar 17,5\% ( $F=13,178 ; \mathrm{r}=-0,419 ; \mathrm{p}=0,001 ; \mathrm{p}<0,01)$. Hal ini mempertegas penemuan Coffey et al. (2002), yang menyatakan bahwa stresor fisik dan lingkungan tidak hanya sumber stres bagi pasien diabetes, namun stres terkait diabetes juga ditimbulkan dari beban perawatan diri, ancaman komplikasi yang semuanya dapat menurunkan kualitas hidup. Stres akan mempengaruhi perilaku dan pola hidup individu. Pada individu dengan diabetes, stres dapat menyebabkan ketidakpatuhan terhadap tritmen, mengganggu pola hidup dan keberfungsian individu (Lyons \& Chamberlain, 2006).

Pada penelitian yang dilakukan oleh Spencer, Keiffer, Sinco, Palmisano, Guzman, James, Dansby, Feathers, Heisler (2006) ditemukan bahwa stres yang terkait dengan penyakit dapat ditimbulkan dari beban perawatan diri yang terus menerus seperti monitoring kadar gula, pengobatan, memonitor asupan makanan dan berolah raga teratur. Stres yang terkait diabetes ditemukan menjadi kontributor yang signifikan terhadap rendahnya kepatuhan terhadap perawatan diri yang direkomendasikan dan rendahnya kontrol gula darah yang semuanya ini dapat berdampak terhadap keberfungsian diri individu secara interpersonal, sosial dan pekerjaan.

Dari hasil analisis juga ditemukan bahwa optimisme sebagai variabel moderator tidak terbukti mempengaruhi hubungan stresor harian dengan kualitas hidup ( $p=0,902 ; p>0,05$; tidak signifikan). Hal ini menunjukkan bahwa optimisme tidak terbukti dapat memperlemah atau memperkuat hubungan antara stresor harian dengan kualitas hidup, ini berarti tingkat optimisme yang tinggi tidak terbukti dapat menurunkan pengaruh stresor harian terhadap kualitas hidup.

\section{n nitro ${ }^{\text {PDF }}$}

PSIKOISLAMIKA, Jurnal Psikoruy Islam (JPI)

downlosd the free Vol. 8No. 1 Tahun 2011 
Menurut Scheir dan Carver (1985), pada individu yang optimis akan menginterpretasikan stresor lebih sedikit, mengabaikan perasaan negatif dan berupaya mengendalikan stresor serta berfokus pada cara mengatasi masalah. Pada individu dengan diabetes mungkin tidak mendapatkan manfaat yang berarti dari optimisme dalam jangka panjang. Terlebih lagi, penyakit diabetes melitus mensyaratkan keterlibatan aktif pasien dalam proses terapi seperti diet, pengobatan dan olah raga sehingga tingginya optimisme tidak mempengaruhi lemahnya hubungan stresor harian dengan kualitas hidup. Menurut Henningsen dan Priebie (dalam Salmon, 2000), penyakit diabetes merupakan penyakit yang secara sistematis keberadaannya tidak terpisahkan dari diri individu dan mempengaruhi seluruh fungsi dalam tubuh sehingga diperlukan pengelolaan aktif individu yang mengalami penyakit tersebut.

Sejalan dengan proses penyakit dan pengobatan yang dijalani, subjek penelitian tidak hanya menggunakan optimisme ketika stres namun juga menggunakan active coping, efikasi diri, kemandirian dan mendapat dukungan sosial dari lingkungannya. Kemandirian dan dukungan sosial yang tinggi akan memberikan kualitas hidup yang lebih baik pada individu dengan diabetes, begitu pula efikasi diri dan active coping selama tritmen pada individu dengan diabetes akan meningkatkan kualitas hidup (Rose et al., 1998 \& 2002).

Menurut Segerstrom, Taylor, Kemeny, dan Fahey (1998), ada 3 pathway optimisme yaitu a). Mood. Optimisme dapat mengurangi mood negatif yang dapat merubah imun ketika stres; b). Coping. Dispositional optimism dapat menghindari penggunaan coping menghindar, pasif, dan menyerah, yang berhubungan dengan memburuknya status imun dan kesehatan; c). Perilaku Sehat. Optimisme dapat meningkatkan fungsi adaptif pada perilaku sehat. Selanjutnya pada penelitian Segerstrom et al., (1998) ditemukan perbedaan antara dispositional optimism dan situational optimism. Ternyata hasil penellitian membuktikan bahwa optimisme situasional merupakan prediktor mood yang lebih kuat daripada optimisme disposisional. Hal ini disebabkan karena optimisme situasional memprediksi perubahan imun, sementara optimisme disposisional tidak memprediksi perubahan imun. Apabila kita mencermati bahwa optimisme disposisional merupakan trait construct, pada penelitian ini dijelaskan bahwa kognisi pada situasi yang spesifik mempredikasi situasi lebih baik daripada te trait constructs, karena penilaian pada 
situasi yang spesifik dapat memprediksi reaksi terhadap situasi secara lebih baik daripada pengukuran optimisme secara umum. Menanggapi penggunaan LOT - R sebagai pengukur optimisme disposisional, penelitian ini menyarankan perlunya metodologi dan pengukuran yang menilai aspek kognitif dalam konteks peristiwa baik peristiwa secara umum maupun spesifik.

Pada penelitian ini juga ditemukan bahwa ada hubungan antara stresor harian dan regulasi diri otonom secara bersama-sama dengan kualitas hidup $\left(F=12,024, r=0,613 ; p=0,000 ; p<0,01 ; R^{2}\right.$ $=0,375)$. Hubungan tersebut signifikan pada taraf signifikansi $1 \%$ dengan sumbangan efektif sebesar $37,5 \%$. Hal ini menunjukkan bahwa individu dengan diabetes yang mengalami stresor harian dan menggunakan regulasi otonom dalam menghadapi stres, akan memiliki kualitas hidup yang lebih baik. Regulasi diri otonom sebagai varibel moderator ternyata terbukti menentukan pengaruh stresor harian dengan kualitas hidup $(p=0,004 ; p<0,05)$. Ini berarti regulasi diri otonom dapat menurunkan pengaruh stresor harian terhadap kualitas hidup.

Pada individu dengan diabetes yang melakukan regulasi diri otonom, ketika mengalami stres masih tetap mampu mempertahankan kualitas hidupnya. Regulasi diri otonom dengan tiga unsur kebutuhan dasar yaitu autonomy, competence dan relatedness mampu menghasilkan kesejahteraan individu. Hal ini dinyatakan oleh Reis, Sheldon, Gable, Roscoe, Ryan (2000) pada penelitiannya yang menemukan bahwa autonomy, competence dan relatedness berperan dalam kesejahteraan harian, karena di dalam regulasi diri otonom terdapat proses realisasi diri yang merupakan sumber kekuatan psikologis yang penting untuk melawan peristiwa yang menekan. Proses realisasi diri menimbulkan bentuk koping yang adaptif dalam menghadapi stres atau tantangan (Miquelon \& Vallerand, 2008). Individu yang memiliki ketiga kebutuhan dasar tersebut akan memiliki tingkat kesejahteraan yang lebih tinggi, karena kesejahteraan harian bukan hanya menghindari dampak negatif dari stresor harian tetapi merupakan kemampuan untuk menghasilkan perasaan positif.

Penelitian Watkins et al. (2000) mengenai pengaruh regulasi diri pada kualitas hidup individu dengan diabetes menunjukkan bahwa regulasi diri dapat meningkatkan pemahaman terhadap penyakit, dan mengurangi rasa terbebani,dari penyakit yang dialami sehingga meningkatkan kepatuhan nada diet dan latiban. Ini menunjukkan 
bahwa regulasi diri otonom juga menghasilkan persepsi terhadap otonomi dan meningkatkan rasa kompeten (Williams et al., 2004).

Selanjutnya hasil analisis data menemukan bahwa regulasi diri terkontrol terbukti sebagai mediator hubungan stresor harian dengan kualitas hidup, dengan taraf signifikansi 5\% ( $p=0,045)$. Ini berarti bahwa stresor harian akan mempengaruhi kualitas hidup melalui regulasi diri terkontrol. Stres akan mempengaruhi regulasi diri terkontrol, dan regulasi diri terkontrol selanjutnya dapat mempengaruhi kualitas hidup. Artinya tingkat stres yang tinggi akan menurunkan regulasi diri terkontrol dan rendahnya regulasi diri terkontrol dapat menurunkan kualitas hidup.

Ketika individu mengalami stres, ia akan menunjukkan perilaku yang tidak sehat seperti memakan makanan yang kurang baik dan tidak berolah raga secara teratur. Hal ini menunjukkan kontrol terhadap perilaku menjadi rendah. Individu dengan regulasi diri yang terkontrol, perilakunya akan dikontrol oleh tekanan interpersonal atau tekanan intrapsikis, sehingga merasa tertekan untuk berperilaku tertentu (McCraty, Atkinson \& Lipsenthal, 2008). Pada saat individu memiliki tingkat regulasi diri terkontrol, maka bentuk regulasi diri individu menjadi external dan introjection. Kedua bentuk regulasi terkontrol ini merupakan bentuk regulasi yang berhubungan dengan perilaku ketidakpatuhan (Ryan, Patrick, Deci, Williams, 2008). Lebih lanjut Ryan et al. (2008) mengatakan bahwa melalui external dan introjections regulation maka tiga kebutuhan dasar individu yaitu competence, autonomy dan relatedness menjadi rendah sehingga dapat meningkatkan depresi, kecemasan, somatisasi dan menurunkan kualitas hidup.

Data sosiodemografi menggambarkan bahwa subjek dengan usia terbanyak antara 50 tahun sampai dengan 60 tahun sejumlah $73,43 \%$, berjenis kelamin perempuan sebanyak 79,68\% dengan pekerjaan ibu rumah tangga sebanyak $51,56 \%$, dan lama penyakit antara 1 tahun sampai dengan 5 tahun sebanyak 56,25\%. Hasil kategorisasi subjek didapatkan bahwa sebanyak $50 \%$ subjek memiliki kualitas hidup yang tinggi dan sebanyak 96,87\% subjek memiliki tingkat stresor harian yang sangat rendah dengan tingkat regulasi diri otonom sangat tinggi $100 \%$ dan tingat regulasi diri terkontrol dengan kategori sedang sebanyak 65,62\%.

Berdasarkan data sosiodemografi juga ditemukan bahwa tidak ada perbedaan antaratiama diabetes dan usia subjek dengan 
kualitas hidup. Berbagai penelitian yang menguji dampak diabetes pada kualitas hidup juga menunjukkan tidak ada hubungan yang signifikan antara faktor usia, lama diabetes dan pendidikan dengan kualitas hidup (Sriram, Sridhar, \& Madhu, 2001). Hal ini mungkin dapat dijelaskan oleh teori Shontz mengenai adaptasi pada penyakit kronis.

Menurut Shontz (dalam Salmon, 2000), seseorang yang mengalami penyakit kronis akan melakukan adaptasi terhadap penyakitnya. Adaptasi penyakit kronis memiliki tiga tahap yaitu 1). Shock. Tahap ini akan muncul pada saat seseorang mengetahui diagnosis yang tidak diharapkannya; 2). Encounter Reaction. Tahap ini merupakan reaksi terhadap tekanan emosional dan perasaan kehilangan; 3). Retreat. Merupakan tahap penyangkalan pada kenyataan yang dihadapinya atau menyangkal pada keseriusan masalah penyakitnya; 4). Reoriented. Pada tahap ini seseorang akan melihat kembali kenyataan yang dihadapi dan dampak yang ditimbulkan dari penyakitnya sehingga menyadari realitas, merubah tuntutan dalam kehidupannya dan mulai mencoba hidup dengan cara yang baru. Menurut teori ini, penyesuaian psikologis terhadap penyakit kronis bersifat dinamis. Proses adaptasi ini jarang terjadi pada satu tahap. Pada beberapa pasien, dapat terjadi secara berulang setiap kali menghadapi tantangan baru dan merespon kehilangan. Sementara itu pada pasien lainnya, beberapa tahap ini dapat terlewatkan. Berdasarkan penjelasan teori tersebut maka dapat disimpulkan bahwa faktor adaptasi terhadap penyakit sangat bervariasi pada setiap orang, dengan proses yang dinamis dan dapat berulang sehingga faktor faktor usia, lama sakit dan pendidikan tidak berpengaruh secara signifikan.

Penelitian ini memiliki beberapa kendala dan kelemahan. Hambatan yang dialami selama penelitian adalah situasi dan kondisi subjek penelitian yang tidak memungkinkan saat dilakukan pengambilan data, antara lain kondisi kesehatan subjek yang kurang baik seperti kelelahan dan badan terasa lemas sehingga subjek yang memenuhi kriteria seringkali tidak dapat mengisi skala yang diberikan. Selain itu, waktu yang digunakan untuk pengisian data terbatas karena subjek penelitian hanya dapat mengisi skala pada pagi hari, saat antrian, sesaat sebelum dilakukan pemeriksaan oleh dokter. Pengisian skala setelah pemeriksaan dokter tidak dapat dilakukan karena subjek harus segera mengambil obat yang 
memerlukan antrian lebih lama dengan jarak yang cukup jauh antara apotek dengan poliklinik, sehingga subjek merasa keberatan untuk melanjutkan proses pengambilan data.

Adapun keterbatasan dalam penelitian ini adalah keterbatasan dalam pengukuran kualitas hidup. Metode skoring yang digunakan diambil dari internet yang mengambil metode skoring dari manual skala kualitas hidup, namun peneliti tidak memperoleh manual aslinya. Selain itu, jumlah aitem yang digunakan masih terlalu banyak, terutama jika dikaitkan dengan kondisi kesehatan subjek yang kurang baik sehingga menjadi hambatan dalam pengisian skala. Pada skala penelitian juga belum menggunakan bahasa Jawa sehingga cukup menyulitkan bagi beberapa subjek yang memiliki keterbatasan dalam memahami bahasa Indonesia.

\section{Kesimpulan}

Berdasarkan hasil penelitian dan pembahasan, maka terdapat beberapa kesimpulan dan saran sebagai berikut:

a. Ada hubungan antara stresor harian, optimisme, regulasi diri dengan kualitas hidup individu dengan diabetes melitus tipe 2. Hubungan tersebut signifikan pada taraf signifikansi $1 \%$ dengan sumbangan efektif sebesar 29,6\%. Dengan demikian hipotesis mayor diterima.

b. Ada hubungan yang signifikan antara stresor harian dengan kualitas hidup. Hubungan tersebut signifikan pada taraf signifikansi $1 \%$ dengan sumbangan efektif sebesar 26,5\%. Dengan demikian hipotesis minor pertama diterima.

c. Optimisme tidak terbukti menentukan hubungan stresor harian dengan kualitas hidup. Artinya tingkat optimisme yang tinggi tidak dapat menurunkan pengaruh stresor harian terhadap kualitas hidup. Dengan demikian hipotesis minor kedua ditolak.

d. Regulasi diri otonom sebagai varibel moderator terbukti mempengaruhi hubungan stresor harian dengan kualitas hidup dengan taraf signifikansi $1 \%$. Ini berarti bahwa regulasi diri otonom dapat memperlemah hubungan stresor harian terhadap kualitas hidup. Dengan demikian hipotesis minor ketiga diterima. 
e. Regulasi diri terkontrol terbukti sebagai mediator hubungan stresor harian dengan kualitas hidup, dengan taraf signifikansi $5 \%$. Ini menunjukkan bahwa stresor harian berpengaruh terhadap kualitas hidup melalui regulasi diri terkontrol. Dengan demikian hipotesis minor keempat diterima.

Dari hasil penelitian tersebut, maka peneliti menyarankan:

a. Bagi Pasien Diabetes

Pasien diabetes perlu memahami adanya pengaruh stresor harian terhadap kualitas hidup. Mengenali adanya stresor dan mengelolanya merupakan hal yang penting untuk meningkatkan kualitas hidup pasien diabetes. Peningkatan pada kemampuan regulasi diri otonom terbukti dapat menurunkan pengaruh stresor harian terhadap kualitas hidup.

\section{b. Bagi Peneliti Selanjutnya}

Peneliti dapat menggunakan faktor lain sebagai mediator dan moderator yang dapat memberikan perbedaan sumbangan terhadap pengaruh stresor harian pada kualitas hidup, seperti: efikasi diri terkait diabetes, kepatuhan, dukungan sosial dan aspek komunikasi dokter dalam memberikan edukasi pada pasien diabetes. Penelitian kolaborasi dengan tim kesehatan lain juga menarik terutama melibatkan faktor medis dalam penelitian kualitas hidup seperti mengaitkan variabel stres dengan pengukuran kadar gula darah.

\section{c. Bagi Ahli Psikologi Klinis dan Kesehatan}

Psikolog klinis dan kesehatan dapat memperhitungkan adanya sumbangan stres harian dan regulasi diri terhadap kualitas hidup pasien diabetes. Hal ini dapat menjadi dasar dalam prevensi dan promosi perilaku sehat, serta manajemen stres untuk mempertahankan kualitas hidup pasien diabetes.

\section{d. Bagi dokter, edukator diabetes dan rumah sakit}

Dokter dan eduktor diabetes dapat mengetahui pentingnya faktor stres dalam pengelolaan pasien diabetes dan peningkatan kemampuan regulasi diri otonom pasien untuk meningkatkan kualitas hidup sehingga pengobatan diabetes tidak hanya difokuskan pada fisik semata tetapi juga memhertittungkan aspek psikologis pasien. 
Hasil penelitian ini membuktikan bahwa kualitas hidup individu dengan diabetes akan tercapai jika individu memiliki stresor harian yang rendah dan memiliki regulasi diri otonom. Kedua variabel tersebut penting untuk mencapai kualitas hidup yang baik, sehingga Rumah Sakit sebagai pembuat kebijakan perlu melakukan tindak lanjut melalui pembuatan Standar Operasional Prosedur (SOP) yang bersifat multidisiplin, dengan menyertakan aspek psikologis dalam tata laksana penanganan pasien diabetes sehingga penanganan pasien dapat dilakukan secara komprehensif.

\section{Daftar Pustaka}

Akimoto, M., Fukunishi, I., Kanno, K., Oogai, Y., Horikawa, N., Yamazaki, T., \& Morokuma, Y. (2004). Psychosocial predictors of relapse among diabetes patients: a 2-Year Follow-Up After Inpatient Diabetes Education. Psychosomatics, 45 (4).

Asdie, A.H. (2000). Patogenesis dan Terapi Diabetes Melitus Tipe 2. Medika Fakultas Kedokteran Universitas Gadjah Mada: Yogyakarta.

Coffey, J., Brendle, M., Marriott, D., Burke, R., Tabaei, B.P., Engelgau, M.M., Kaplan, R.M \& Herman, W.H. (2002). Valuing health-related quality of life in diabetes. Diabetes Care, 25 (12).

Goldney, R.D., Phillips, P.J., Fisher, L.J., Wilson, D.H. (2004). Diabetes, depression and quality of life. A population study. Diabetes Care, 27:1066 - 1070 .

Lyon, A. C., \& Chamberlain, K. (2006). Health Psychology. A Critical Introduction. Cambridge University Press.

Mc Craty, R., Atkkinson, M., Lipsenthal, L. (2000). Emotional self regulation program enhances psychologycal health and quality of life in patients with diabetes. Proceeding of The Sociaty of Behavioral Medicine $20^{\text {th }}$ Anual Scientific Session.

Milenkovic, T., Gavrilovic, S., Percan, V., \& Petovski, G. (2004). Influence of diabetic education on patient well-Being and metabolic control. Diabetologia Croatica, 33 (3).

Miquelon, P., \& Vallerand, J. (2008). Goal motives, well - being and physical health: An integrative model. Canadian Psychology, 49 (3), 241 - 249.

Nakahara, R., Yoshiuchi, K., Kumano, H., Hara, Y.,Suematsu, H., \& Kuboki, T. (2006). Prospective factors on glicemic control in japanese patients with type 2 diabetes. Psychosomatic, 47, 240-246.

Petrie, K. J., Broadbent, E., \& Meechan, G. (2002). Self Regulatory Intervention for Improving The Managementipf Chronic Illness. 
Perkeni. (2008). Materi Edukasi Diabetes. http://www.perkeni.net/index. php?page=proyek improving diabetes health.

Pitts, M., \& Phillips, K. (1991). The Psychology of Health. An Introduction. Routledge, Chapman \& Hall. Inc.

Polonsky, W. H., Fisher, L., Earles, J., Dudl, R. J., Lees, J., Mullan, J. J., \& Richard, A. (2005). Assessing psychosocial distress in diabetes. development of the diabetes distress scale. Diabetes Care, 28 (3).

Prokop, C. K., Bradley, L. A., Burish, T. G., Anderson, K. O., \& Fox, J. E. (1991). Health Psychology. Clinical Methods and Research. Mac Millan Publishing Company. New York.

Reis, H.T., Sheldon, K.M., Gable, S.L., Roscoe, J., Ryan, R.M. (2000). Daily Well - Being : The role of autonomy, competence, and relatedness. Personality \& Social Psychology Buletin, 26 (4), 419 - 435.

Riazi A., Pickup J \& Bradley, C. (2004). Daily stress and glicaemic control in type 1 diabetes: Individual differences in magnitude, direction and timing of stress-reactivity. Diabetes Research and Clinical Practice, 66 (3), 237-244.

Rose, M., Fliege, H., Hildebrandt, M., Schirop, T., \& Klapp, B. (2002). The network of psychological variables in patient with diabetes and their importance for quality of life and metabolic control. Diabetes Care, 25, 35-42.

Rose, M., Burkert, U., Scholler, G., Schirop, T., Danzer, G., \& Klapp, B. (1998). Determinant of the quality of life of patients with diabetes under intensified insulin theraphy. Diabetes Care, 21 (11).

Ryan, R.M., Patrick, H., Deci, E.L., Williams, G.C. (2008). Facilitating health behavior change and its maintenance: Interventions based on selfdetermination theory. The European Health Psychologist, 10 (3).

Salmon, P. (2000). Psychology of Medicine and Surgery. A Guide for

Psychologist, Counselors, Nurses and Doctors. Wiley Series in Clinical Psychology. John Willey \& Sons, Ltd.

Scheier, M.F., \& Carver, C.S. (1985). Optimism, coping and health: assessment and implications of generalized outcome expectancies. Health Psychology, 4, 219-247.

Segerstrom, S.C., Taylor, S.E., Kemeny, M.E., Fahey, J.L. (1998). Optimims is associeted with mood, coping, and immune change in respones to stress. Journal of Personality and Social Psychology. 74 (6), $1646-1655$.

Serido, J., Almeida, D.M., Wethington, E. (2004). Chronic stressor and daily hassless: Unique and interactive relationship with psychologycal distress. Journal of Health \& Social Behavio, 45 (1).

\section{Created with}

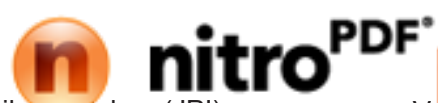


Spencer, M. S., Keiffer, E. C., Sinco, B. R., \& Palmisano, G. (2006). Diabetesspecific emotional distress among african americans and hispanics with type 2 diabetes. Journal of Health Care for the Poor and Underserved, 17 (2). ProQuest Medical Library.

Sriram, V., Sridhar, G.R., Madhu, K. (2001). Gender differences in living with type 2 diabetes. Int, J. Diab. Dev. Countries, 21.

Vitaliano, P. P., Scanlan, J. M., Krenz, C., \& Fujimoto, W. (1996). Insulin and glucose: Relationship with hassless, anger and hostility in nondiabetic older adults. Psychosomatic Medicine, 58, 489-499.

Watkins, K. W., Connell, C. M., Fitzgerald, J. T., Klem, L., Hickey, T., \& Dayton, B. I. (2000). Effect of adult's self regulation of diabetes on quality of life outcomes. Diabetes Care, 23, 1511-1515.

Williams, G. C., Freedman, Z. R., \& Deci, E. L. (1998). Supporting autonomy to motivate patient with diabetes for glucose control. Diabetes Care, 21 (10), 1644-1651.

Williams., Fredman., \& Deci. (2004). Testing a self-determination theory process model for promoting glycemic control through diabetes self-management. Health Psychology, 23 (1), 58-66.

Wrosch, C \& Scheier, M. F. (2003). Personality and quality of Life: the importance of optimism and goal adjustment. Quality of Life Research. 